\title{
CHAPTER 2
}

\section{The Political Context}

COMSA's main objective has been to assist with efforts to contain the political violence which has threatened the negotiating process in South Africa. In both of its previous reports, the mission stressed that while it would be naive to assume that violence would end overnight with a new political dispensation, a democratically elected government stood a far better chance of coming to grips with violence than one which represented only a privileged minority.

At the time that COMSA released its second report in May 1993, multiparty negotiations had just resumed after a suspension occasioned by political violence. During the third phase, these negotiations reached their climax, with agreement on transitional arrangements leading to elections for a Constituent Assembly and an Interim Constitution.

Yet, as Commonwealth Heads of Government noted in their Cyprus Communiqué, the process remains 'fragile'. During the course of the talks four groups - the Inkatha Freedom Party (IFP), the Conservative Party (CP) and the 'homelands' of Bophuthatswana and Ciskei - withdrew from negotiations.

These groups, along with the Afrikaner Volksfront (AV), an umbrella for conservative organisations demanding a separate Afrikaner state, formed the Freedom Alliance which - at the time of writing - had refused to take part in the transitional arrangements. It remained unclear whether or not this coalition or its individual members would contest the elections.

On the other hand, the Pan-Africanist Congress (PAC) said that while it would contest the elections, it would not participate in transitional arrangements. The Azanian People's Organisation (AZAPO) stated that it would not contest the elections.

During the third phase of COMSA, we continued contact with a broad range of political parties and interest groups including: the National Party (NP); the African National Congress (ANC); the IFP; the Democratic Party (DP); the PAC; the Afrikaner Volksfront; South African Council of Churches; Consultative Business Movement; Institute for Multi-party Democracy; and Institute for Democratic Alternatives in South Africa (IDASA).

We held discussions with members of the technical committees drafting the Interim Constitution, Transitional Executive Council Act, and the Commission responsible for delimiting new regional boundaries. COMSA also 
attended in an observer capacity the constitutional negotiations, and met informally with many of the negotiators at the talks which took place at the World Trade Centre in Kempton Park.

In the course of his three-day visit to South Africa, the Commonwealth Secretary-General attended the 18 November plenary of the multi-party negotiations which endorsed the transitional agreements. He subsequently met with State President FW de Klerk; ANC leader Nelson Mandela; IFP leader Chief Mangosuthu Buthelezi; PAC Chairman Johnson Mlambo; DP leader Zach De Beer, and AV leader General Constand Viljoen.

From all these contacts, we formed the view that the transitional agreements and arrangements offer a promising point of departure for South Africa's progress to a democratic and non-racial society.

Our strongest plea in this Report is that those remaining outside these arrangements return or join the process and contest South Africa's first democratic elections. We also urge that the issue of the 'homelands', which presents serious challenges in the run-up to elections, be addressed as a matter of urgency.

\section{Securing Agreement on Transitional Arrangements}

For over three years since President de Klerk pledged to dismantle apartheid, efforts to reach agreement on transitional arrangements that would finally lead to democratic elections, and the adoption of a new constitution, ebbed and flowed.

The Convention for a Democratic South Africa (CODESA) came to a halt in May 1992, in part over continued allegations of state involvement in political violence. In its first Report, COMSA, among many others, urged that negotiations should not be held hostage by the violence, since delaying negotiations would only fuel more violence.

This principle was eventually accepted, as an even more representative group of 26 political parties and interest groups gathered this April at the World Trade Centre in a renewed effort to resolve the political conflict.

The determination of those involved to make progress is underscored by the fact that, when the negotiators failed to agree on a name for the negotiations they pressed ahead regardless.

On 15 June 1993, the Negotiating Council agreed by 'sufficient consensus' to hold elections on 27 April 1994. COMSA, which in its first Report stressed the importance of fixing an election date, to give the country 'a different sort of battlefield', hailed this development.

In early July 1993, the IFP and the CP withdrew from the talks, protesting against the two-phase process agreed on for the transition and the use of the 'sufficient consensus' mechanism to reach agreement on an election date. The mechanism, and the agreement, were subsequently upheld in the Supreme Court. 


\section{THE NEGOTIATING PROCESS UNTIL THE ELECTION}

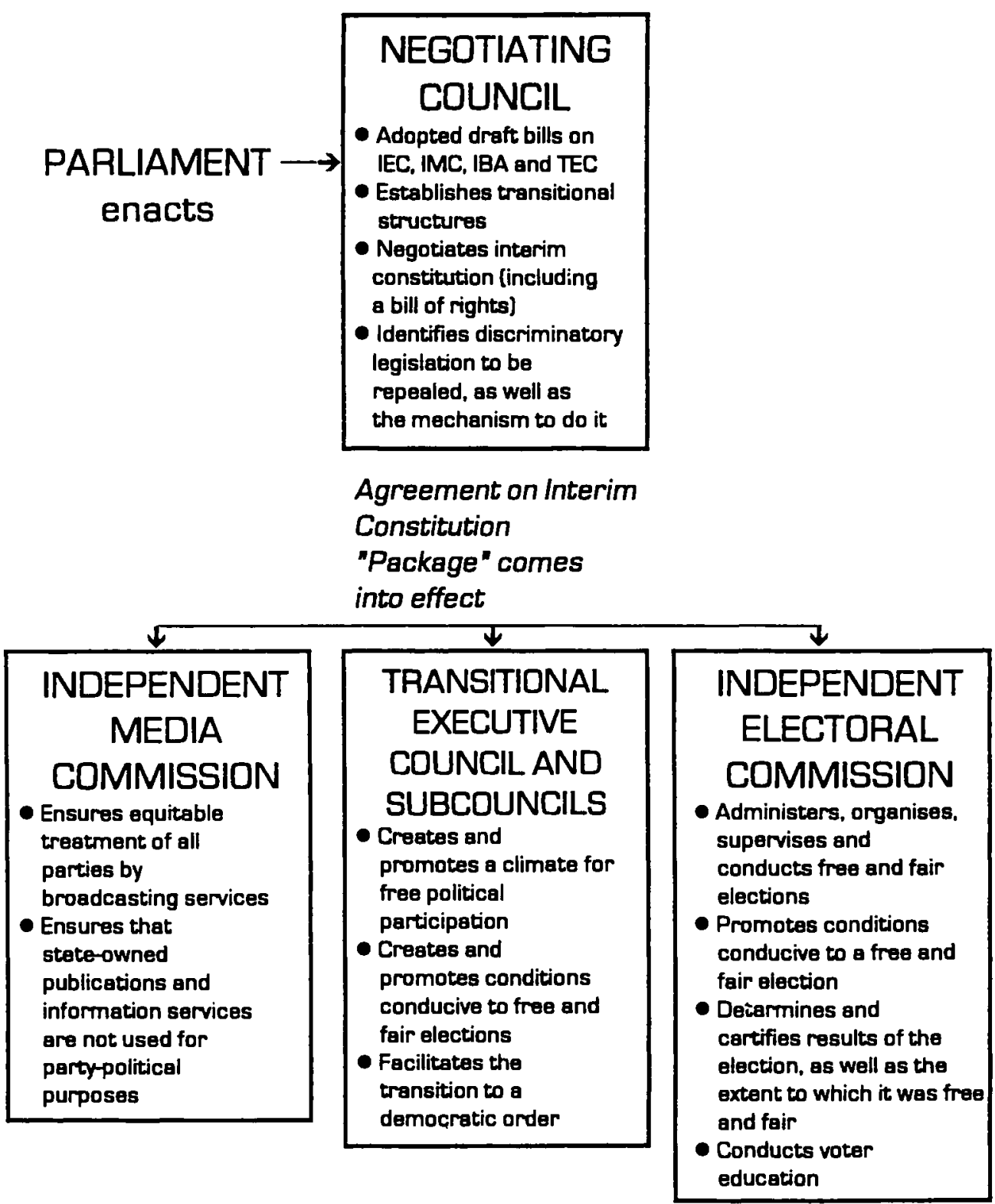

LEVELLING THE POLITICAL PLAYING FIELD

$\downarrow$

FREE AND FAIR ELECTION - APRIL 1994

Source: Consultative Business Movement 
On 23 and 24 September 1993, the four pillars of the transition agreed at the World Trade Centre - the Transitional Executive Council (TEC), the Independent Electoral Commission (IEC), the Independent Media Commission (IMC) and the Independent Broadcasting Authority (IBA) - were enacted by Parliament. The relationship between these is illustrated in Table 1.

The Commonwealth Secretary-General described the passage of these bills as an 'historic watershed' which marked the 'irreversibility of the ending of apartheid', and led to the lifting of remaining economic sanctions by Commonwealth governments and the wider international community.

Further difficulties were encountered in the negotiations when the two 'homelands' of Ciskei and Bophuthatswana, associated with the IFP and CP in the then Concerned South Africa Group (COSAG), withdrew, vowing not to incorporate the TEC legislation into their laws. The Freedom Alliance, launched in early October 1993, cemented the pact among the groups that had decided to boycott the talks.

While bilateral negotiations continued in an effort to draw the Freedom Alliance back into the talks, the 22 groups remaining in the talks at Kempton Park soldiered on.

Adhering to an earlier agreement that none of the legislation would become operational until the entire package had been agreed, negotiators returned to the table to find common ground on an Interim Constitution, an Electoral Act, and the removal of remaining apartheid laws.

Working against gruelling deadlines, the Negotiating Council finally delivered the full package of agreements for endorsement at a plenary session in the early hours of 18 November 1993.

At its historic last sitting in Cape Town in late 1993, South Africa's tricameral parliament was to end its existence with the repeal of remaining apartheid legislation, adoption of the Interim Constitution and Electoral Acts. At the time of writing, the four transitional pillars - the TEC, IEC, IMC and IBA - were coming into operation.

In seven months, South Africans from a broad political spectrum ranging from the Afrikaner Volksunie (the conservative Afrikaner group which remained in the talks) to the South African Communist Party (SACP) succeeded in finding a formula for the transition to a multi-party, non-racial democracy.

The achievements of this period are all the more noteworthy because of:

- the fact that this formula is an entirely South African solution, with the international community playing only a very limited, supportive role.

When the negotiations began, there were suggestions that an international mediator might be required. In the event, the majority of parties opted not to seek outside assistance. At times, not having a third party to play referee might have delayed the process. But the significance of insisting on a domestic solution is that after centuries of separation, 


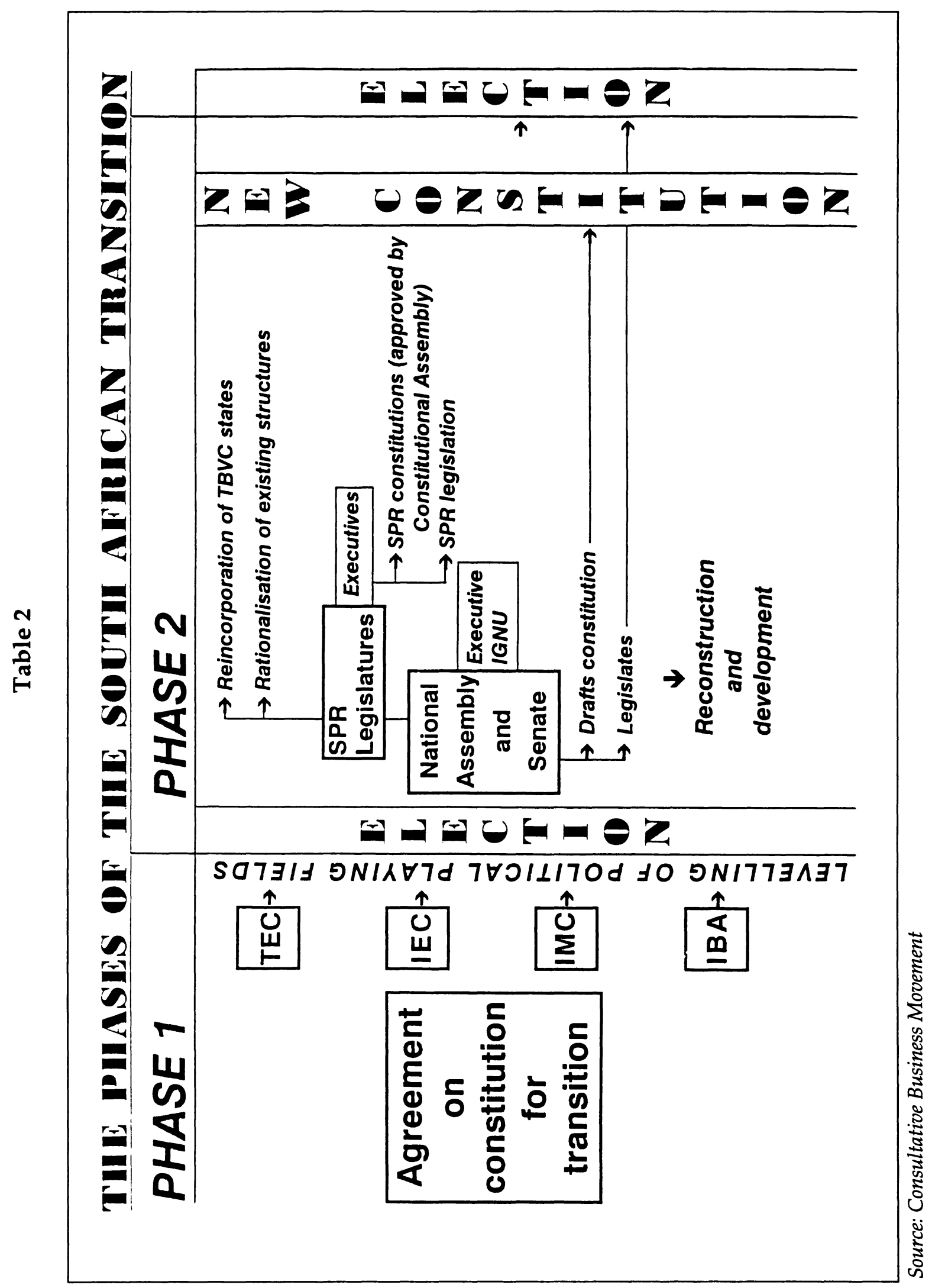


South Africans were forced to confront each other and each other's worst fears.

- the degree of inclusiveness, and role afforded to every player. In its first Report, COMSA stressed the importance of making the talks as inclusive as possible, even if this meant slowing down the process.

All groups with a stake in South Africa's future were invited to Kempton Park. We note the objection to the sufficient consensus mechanism but believe that short of unanimity, it was the best possible procedure.

The system of rotating chairpersons - cumbersome and inefficient at times - gave each group a chance to steer the talks at some point. And the parallel bilateral talks, which continued after the formation of the Freedom Alliance, are a testimony, in our view, to the continued desire for all South Africans to play a part in the process.

- the building of a culture of consultation. Despite the violence and political intolerance which continue to bedevil South Africa, and which wediscuss in greater detail elsewhere in this Report, the Kempton Park talks have set in motion a culture of consultation which has begun to filter down to the grassroots.

This habit of talking things over, no matter how difficult the problem, is an important legacy of the transitional period for the new South Africa.

- the negotiations were throughout characterised by a spirit of give and take. At the beginning, for example, the ANC wanted the full task of drafting a constitution to be borne by the Constituent Assembly. In the end, it agreed to an Interim Constitution, with 32 constitutional principles with which a final constitution would have to conform.

As part of its 'power sharing' proposals, the Government had argued for a system of rotating presidents. It eventually conceded to a system of executive vice-presidents, with whom the President will have to consult as described later in this chapter under the section on the Interim Constitution.

Evidence of compromise abounds in the Interim Constitution. For example, on the controversial issue of which official language to adopt (English and Afrikaans are currently the official languages of South Africa), the negotiators agreed to 11 official languages, with each province choosing which two it wants to use.

\section{Stages of the Transition}

The transitional process, as agreed, is in two stages, illustrated diagrammatically in Table 2 . They are as follows:

- a transition period in which the TEC supervises key arms of Government that have a bearing on levelling the playing field for free and fair elections. 


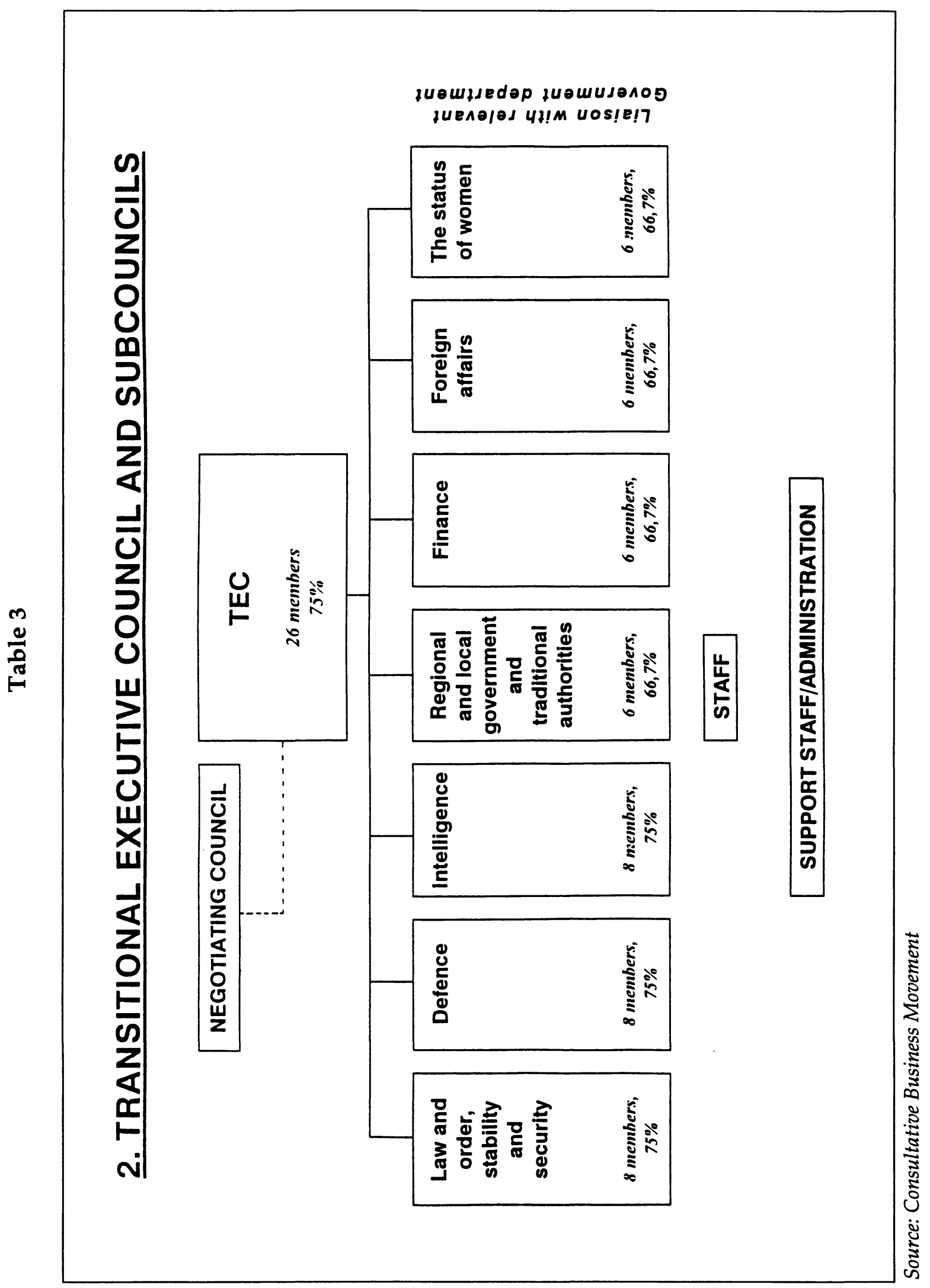


- elections to a Constituent Assembly which both finalises the constitution during its first two years and serves as the country's Parliament. After the first two years, the Constituent Assembly will continue as the country's Parliament, until the next elections in 1999.

Some noteworthy features of this process, which seek to provide safeguards against excesses by any one party, are as follows:

- The Constituent Assembly, in drafting the final constitution, will be bound by 32 constitutional principles contained in the Interim Constitution. These guarantee, among other things, a multi-party democracy, three tiers of government and the recognition of civil liberties. The principles also enshrine broad parameters for the devolution of power to the regions.

- The Constitution will have to be approved by a two-thirds majority of a joint sitting of Parliament, comprising a 400-person National Assembly and 90-person Senate.

- Should a two-thirds majority fail to agree on the final constitution, the deadlock breaking mechanism agreed in the multi-party negotiations provides for a referendum in which 60 per cent of the voters would have to approve the constitution in order for it to be passed.

- The final constitution will have to be vetted by a Constitutional Court to ensure that it is in keeping with the constitutional principles agreed at the talks in Kempton Park.

This court will have the final say on matters relating to the interpretation, protection and enforcement of all provisions of the constitution.

After considerable and sometimes acrimonious debate, the method for appointing the Judges to this potentially powerful court was amended to give the Judicial Services Commission an influential role in the selection of the judges, previously left almost entirely to the discretion of the President.

\section{The Transitional Executive Council}

The transitional arrangements rest on four pillars: the TEC, IEC, IMC and IBA. The last three of these institutions are discussed in Chapters 7 and 8. Overarching these three is the TEC, supported by seven sub-councils. These are illustrated in Table 3.

The TEC draws its membership from the negotiating parties which have pledged their support to the objects of the Council. These parties include:

- the Government;

- parties or political organisations involved in the negotiations;

- the TBVC 'states' (that is, the 'homelands' of Transkei, Bophuthatswana, Venda and Ciskei) which agree to incorporate into their statutes the 
provisions of this Act, the IEC, Electoral, IBA and IMC Acts (only Transkei and Venda have so far taken these measures).

The objectives of the TEC are to: eliminate any impediments to legitimate political activity and intimidation; ensure that political parties are free to canvass support and hold meetings; ensure the full participation of women; and ensure that no government or administration exercises any of its powers in such a way as to advantage or prejudice any political party.

The TEC is empowered to 'request and obtain information in regard to, any decision and any proposed or intended action of that Government, administration or political party or organisation likely to have a bearing on the objects of the Council.' It can direct any Government or administration not to proceed with any legislation likely to 'have an adverse effect on the attainment of the objectives of the Council.'

After protracted debate at Kempton Park, it was agreed that the TEC should take decisions by a 75 per cent majority, except in matters relating to defence, in which an 80 per cent majority would be required.

Seventy-five per cent majorities will be required in the sub-councils of Law and Order, Defence and Intelligence, which will each comprise eight members (i.e. three members would have to vote 'no' for a decision to be blocked).

A lower 66.5 per cent majority vote is required for decisions in the subcouncils on Local Government and Traditional Authorities, Finance, Foreign Affairs and the Status of Women, which will each comprise six members (again, to block a decision, three members would have to vote against a motion).

How the TEC will work in practice remains to be seen. There is no historical precedent to this arrangement in which all parties contesting the elections supervise the existing government in its handling of these elections.

The duration of the TEC is likely to be short. It could be argued that the Council and its sub-council's will barely have time to find their feet, let alone delve into all the information to which they have access, before it is time for the elections to be held.

We firmly believe, however, that:

- The culture of negotiations and compromise built up at Kempton Park, rather than mathematical formulae, will be the most important factor in ensuring the smooth functioning of the TEC. Here, the observer role of the international community, which we discuss in greater detail in the concluding chapter, will be especially important.

- The TEC should adhere to its mandate of focusing on matters relating to the elections.

One of the dangers we foresee in the transitional period is that many South Africans, who have waited for decades for a new political dispensation, may have unrealistic expectations of the TEC. 
On the positive side, the TEC will provide the opportunity for groups that have so far been excluded from Government to understudy many functions. This can only be beneficial to the new administration.

\section{The Interim Constitution}

Despite various criticisms of the Interim Constitution, we believe that it provides South Africa with a firm basis for a new beginning. Some of its salient features are:

\section{A Government of National Unity}

South Africans had the choice, in deciding on transitional arrangements, to opt for the usual system in a democracy in which the majority party forms the government, and the others form the opposition, or to find a more inclusive formula.

The provisions for a Government of National Unity, in which parties with as little as five per cent of the vote will have a voice, is in our view a magnanimous gesture, which should help to allay minority fears.

Key features include:

- any party with more than five per cent of the vote will be entitled to seats in Cabinet. Although the present Government failed in its bid to secure a percentage vote by which Cabinet would take decisions, the final agreement encourages consensus to be sought wherever possible.

- a President, elected by a simple majority in Parliament (to avoid a separate presidential election), with considerably less powers than in the present Constitution.

- any party with 20 per cent of the votes, or if there are none except for the winning party, this party and the second largest party, will nominate Executive Deputy Presidents with whom the President must consult on major decisions including the allocation of portfolios in Cabinet. This provision assures minority parties a say in executive decisions.

- the above arrangements are to last for five years, i.e., three years beyond the adoption of the final constitution, and until the next election. These provisions, and the time frame, should reassure many of those who are still apprehensive over majority rule.

\section{Fundamental Rights}

The Interim Constitution contains a Chapter on Fundamental Rights which benefits from contemporary experience, containing several features which older democracies have had to incorporate, or are still debating.

Examples of these are the provision for gender equality; the right not to be discriminated against on the basis of sexual preferences, and the right of 
every person 'to an environment which is not detrimental to his or her well being.'

The Chapter empowers a variety of persons and institutions: academic freedom is guaranteed; detainees are protected from abuse; minority language groups are entitled to their languages and cultural life; and education is deemed a universal right rather than a privilege.

However, the Chapter is also the product of tough negotiations and compromise, which has in parts resulted in awkward wording. The right to property, for example, has been qualified to allow for land reform, and that has in turn been qualified to prevent unfair expropriation. The final wording seems to leave considerable latitude for different interpretations.

Certain controversial issues remain. For example the 'right to life', does not specify the implications of this clause for abortion or capital punishment.

In an attempt to come to terms with the debate over whether or not human rights are socio-economic as well as political, this section of the Interim Constitution guarantees every child the right to education, security, basic nutrition, health and social services. This raises a number of questions: how childhood is defined, what is basic nutrition, health and social services, and whether or not adults should not be entitled to the same. These sorts of issues will have to be addressed in debates on the final constitution, or be left to the courts to decide.

They are, however, matters of detail which rest on a solid foundation of respect for human rights.

\section{Delimitation of Provinces and Provincial Powers}

The relationship between central and regional governments proved to be one of the most controversial in the negotiations, driven primarily by the demands of the groups which later withdrew from the negotiations.

At the one level, this has involved redrawing the map of South Africa to reshape its four administrative areas, the ten self governing 'homelands' and the TBVC 'states' into nine new provinces.

After much debate on this issue, it has finally been agreed that the nine boundaries initially recommended by the Delimitation Commission be included in the Interim Constitution for the purposes of the elections, with provision for changes to take place either through consensus being reached before the elections, or by referenda after the elections.

Among the controversial points are:

- whether or not Pretoria should be part of the Pretoria/Witwatersrand/ Vaal industrial heartland (as favoured by the business community) or part of the Northern Transvaal province (as favoured by some of the Afrikaner population of the city). 
- whether or not the Eastern Cape should be one region -incorporating the two 'homelands' of Ciskei and Transkei (as currently advocated by the Commission) - or be split into two regions.

- the proposed Northern Cape province, which has little economic rationale, but comes closest to accommodating the demands of right-wing Afrikaners for a separate state.

We appreciate why it has been necessary to defer final decisions on regional boundaries. However, conscious of the potential for conflict generated by disputes over boundaries, we urge that this issue not be unduly deferred.

Under the Interim Constitution, each province will have its own Legislature, an Executive Council of not more than ten persons and a regional head of government, or Premier. Each party with more than ten per cent of the provincial vote will be entitled to seats in Cabinet on a proportional basis.

Following considerable negotiations, driven largely by the bilateral negotiations between the Government, ANC and Freedom Alliance, significant powers have been devolved to the provinces.

Under the Interim Constitution, national and provincial governments will have concurrent powers in areas such as culture, education, health, welfare, housing, local government, transport, tourism, urban and rural development and trade.

An Act of Parliament can prevail over a provincial law in specific circumstances, such as instances in which it can be proven that a provincial government cannot handle a matter effectively; to ensure 'uniform' or minimum standards, or where a provincial law prejudices the economy of another province or the country as a whole.

These provisions have prompted criticism in some quarters that the central government will give with one hand and take away with the other, thus negating the concept of federalism.

The reality is that even in old established federations, centripetal forces are strong. The extent to which power remains in the provinces depends at least in part on the efforts at provincial level to assert and maintain their power.

In this regard, it is unfortunate that the parties most in favour of a federal solution in South Africa have remained outside or have left the negotiating process. Their case has been further weakened by a lack of clarity on the precise form of state they seek, with some espousing federalism, whileothers-in order to accommodate a separate Afrikaner state - advocate confederalism.

We believe that the Interim Constitution provides a reasonable basis upon which to build both unity and diversity in South Africa. How this works depends on the willingness of all the country's peoples to play a constructive role. This again underscores the importance of all parties joining the transitional arrangements. 


\section{The 'homelands'}

One of the first major challenges that the TEC is likely to have to contend with is the complex issue of the holding of elections in the TBVC 'states'.

Despite an eleventh hour decision by negotiators to include the repeal of legislation creating these entities in the Interim Constitution, it seems unlikely that this will be effected before the elections. This raises several questions regarding the conduct of the elections in these territories, especially in Bophuthatswana and Ciskei.

The issue is one which COMSA has followed closely since the mission began. In its second Report, COMSA detailed its direct experiences in and views on the reincorporation of the 'homelands' as a precondition for free and fair elections.

The Report mentioned the repeal of Section 43 of Ciskei's Internal Security Act, which had made it possible for opposition parties to campaign more freely in the territory. It went on to give an account of the continued existence of oppressive legislation in Bophuthatswana, and the negative attitude of the authorities there towards the presence of international observers.

During the third phase, COMSA, along with the other international observer missions, met with theleader of Bophuthatswana, Mr Lucas Mangope, and his cabinet, to discuss these issues. The Bophuthatswana delegation pledged to reconsider its stance against signing the National Peace Accord, and to set up a task force with the international observer missions to facilitate their access to the territory. Despite repeated queries, nothing came of these pledges.

We turned our attention instead to the more fundamental issue of the reincorporation of all four TBVC'states' into South Africa, which would result in South African laws and transitional arrangements applying in these territories.

At a briefing by the responsible government minister in June, we were given to understand that reincorporation was imminent, and no longer dependent on the earlier idea of holding referenda in these territories. A document prepared by the Government outlined administrative arrangements post reincorporation and during the transition period. There has, however, still been no follow through on this proposal.

The difference between Transkei and Venda on the one hand, and Ciskei and Bophuthatswana on the other, is that while the former have agreed to incorporate TEC legislation into their laws, and allow the IEC, IMC and IBA to operate in their territories, the latter have rejected these measures.

Ciskei's military ruler, Brigadier Oupa Gqozo, is currently standing trial on murder charges. At the time of writing, the future of Ciskei remained uncertain.

In the final hours of the negotiations at Kempton Park, the parties voted to include in the Interim Constitution the repeal of the laws giving 'independence' to the TBVC states, and self governing status to the other 'homelands'. 
However, it is not clear when the repeal is to take effect. The Interim Constitution only takes effect after the elections, which suggests that unless special provisions are made, the repeal of these laws will also only take effect after the elections.

Under the Electoral Act, persons with 'homelands' identification documents are eligible to vote. Venda and Transkei have indicated their willingness to allow theelections to beheld in their territories, whether or not reincorporation has taken place.

Bophuthatswana and Ciskei, on the other hand, have warned that the Act extending the vote to citizens of the 'homelands' cannot be applied 'extra territorially'. In the worst case scenario, this means that voters would have to be transported across the 'borders' of these 'homelands' into South Africa in order to vote.

There will have been no guarantee prior to the elections that political parties campaigned freely in the territories. And the election tribunals will have no jurisdiction over persons in these territories accused of intimidation.

Short of full reincorporation of the TBVC 'states' into South Africa prior to the elections - which in our view would have been the most desirable option - we see no choice but to press Bophuthatswana and Ciskei to permit transitional arrangements in their territory, as has been agreed in Transkei and Venda. They would also have to be obliged to permit the election to take place within their territories, and to allow free access to observers: local and international. 